\title{
The use of videophone technology (telenursing) in the glycaemic control of diabetic patients: a randomized controlled trial
}

\author{
Nurgül GÜNGÖR TAVŞANLI ${ }^{1 *}$, Ayfer KARADAKOVAN² and Füsun SAYGILI ${ }^{3}$ \\ *Correspondence: nurgul.gungor@hotmail.com \\ 'Internal Medicine Nursing, Department of Midwifery, Health Faculty, Celal Bayar University, Manisa, Turkey. \\ ${ }^{2}$ Department of Internal Medicine Nursing, Ege University Faculty of Nursing, Izmir, Turkey. \\ ${ }^{3}$ Department of Endocrinology, Ege University Faculty of Medicine, Izmir, Turkey.
}

\begin{abstract}
Background: Prevention of diabetic complications requires good glycaemic control. This study aimed to provide type 2 diabetes patients with remote active care and glycaemic control through the use of videophone technology without the need for them to attend hospital. The literature recommends additional research to study the impact of technical innovations on improved disease self-management and medical outcome. This is the only study to be conducted in Turkey concerning patient monitoring using videophone technology. The aim of the study was to establish the effectiveness of the use of videophone technology in the glycaemic control of patients with diabetes living in remote areas.

Methods: This is a prospective, randomized control study using the systematic sampling method (using half ratio), in which 24 patients were chosen for the Experimental Group (EG) and another 24 for the Control Group (CG). All of the patients agreed to participate in the study. Patients in the CG received routine care, while the glycaemic control and consultations for patients in the EG were conducted using videophone technology. The patients were monitored by videophone for a total of 6 months. The HbAlc and blood glucose values recorded over the 6 month monitoring period were analyzed to determine the effectiveness of using a videophone.

Results: The mean age of the individuals in the EG was $54.41 \pm 8.54$ years (Min=43 Max=78) and in the CG it was $57.25 \pm 9.61$ $(\mathrm{Min}=40 \mathrm{Max}=77)$. In both groups, $50 \%$ of the individuals were men and $50 \%$ were women. When the two groups were compared, it was was found that the preprandial blood glucose levels of the diabetic patients in the EG (mean $159.48 \pm$ $40.71 \mathrm{mg} / \mathrm{dl}$ ) were lower by $13.55 \pm 52.89 \mathrm{mg} / \mathrm{dl}$ than the preprandial blood glucose levels of the diabetic patients in the CG (mean $173.03 \pm 65.07 \mathrm{mg} / \mathrm{dl}$ ). It was determined at the end of the six-month monitoring that the A1c levels of the individuals in the EG were significinatly lowered by $0.49 \%$ in total, and that the A1c levels of the individuals in the CG were higher by $0.17 \%$ in total.

Conclusions: It was shown that videophone technology can be useful in the glycaemic control of diabetic patients in Turkey. Keywords: Diabetes mellitus, glycemic control, videophone, elecare
\end{abstract}

\section{Introduction}

Diabetes is a leading cause of death and morbidity and is a health priority worldwide. An estimated 285 million people worldwide have diabetes and its prevalence is predicted to increase to 439 million by 2030 [1].

Diabetes is one of the most important non-communicable diseases in Turkeycountry and constitutes a disease burden which is expected to rise even further in the near future $[2,3]$. In the Turkish Diabetes Epidemiology Study (TURDEP) by Satman et al., the prevalence of diabetes mellitus in Turkey was established as $13.7 \%$ and the prevalence of impaired glucose tolerance was $14.5 \%$. The rate of diabetes mellitus and impaired glucose tolerance was also shown to rise along with increases in BMI, waist/ hip ratio and waist circumference [4].
The increase in the use of technology in diabetes treatment facilitates improved communication between nurses and patients, the reliable collection of data, and the provision of a comfortable life to patients $[5,6,7,8]$. Another important purpose of tele-care is to provide patients with the opportunity to maintain their education effectively without interruptions $[\mathbf{9}, \mathbf{1 0}, \mathbf{1 1}]$. Videophone technology, using webcams and with regular telephone consultations, enables patients to maintain their education, and to have treatment at home without the need to attend clinics. Through the use of technical instruments such as videophones, the needs of patients with different metabolic control needs can be met [12].

Videophone technology allows possibilities such as easy face-to-face communication between diabetes

(c) 2013 Gungor Tavisanli et al; licensee Herbert Publications Ltd. This is an Open Access article distributed under the terms of Creative Commons Attribution License (http://creativecommons.org/licenses/by/3.0). This permits unrestricted use, distribution, and reproduction in any medium, provided the original work is properly cited. 
patients and health professionals, the self-monitoring of blood glucose levels and receiving feedback (support and counselling) $[13,14]$. This technology, aimed at type 2 diabetes mellitus (T2DM) patients, generally provides motivational support as well [15].

The literature recommends more research to study the impact of technical innovations on improved disease selfmanagement and medical outcome $[17,18,19]$. The prevention of diabetic complications requires good glycaemic control [16]. This study aimed to provide type 2 diabetes patients with remote active care and glycaemic control through the use of videophone technology without the need for them to attend hospital.

The aim of the study was to establish the effectiveness of the use of videophone technology in the glycaemic control of patients with diabetes.

\section{Material and Methods Design and setting}

This study was planned as a prospective, descriptive, randomized case control investigation. It was carried out in Ege University Faculty of Medicine, Endocrinology and Metabolism outpatient clinic. A total of 361 outpatients, whose ICD10 diagnosis codes were E10 or E14 and whose ICD9 codes were 250, were screened. The researcher telephoned a total of 361 patients, of whom 114 were found to be suitable for inclusion in the study. Using the systematic sampling method (using half ratio), 24 of these patients were chosen for the EG and another 24 for the CG. All agreed to participate in the study (24 was the number designated by Turkish Telekom who sponsored the study).

Systematic sampling is a statistical method involving the selection of elements from an ordered sampling frame. The most common form of systematic sampling is an equal-probability method. In this approach, progression through the list is treated circularly, with a return to the top once the end of the list is passed. The sampling starts by selecting an element from the list at random and then every kth element in the frame is selected, where $k$, the sampling interval (sometimes known as the skip):

this is calculated as: $k=\frac{N}{n}$.

Where $\mathrm{n}$ is the sample size, and $\mathrm{N}$ is the population size. Using this procedure each element in the population has a known and equal probability of selection. This makes systematic sampling functionally similar to simple random sampling. It is however, much more efficient (if variance within systematic sample is more than variance of population) [20].

The universe size $\mathrm{N}=114$ was divided by the sample size $n=24(114 / 24=4.75)$, and was taken as about 5 . A number from 1 to 5 was selected on a simple random number table. The number three was selected. Before the third file from the file 114 arranged in alphabetical order have been sampled. Then, one file from every five was included in the sample, and in this way 24 patients' files were selected. Patients in the CG received routine care, while the glycaemic control and consultations for patients in the EG were conducted using videophone technology.

\section{Inclusion Criteria \\ Patients}

1. Between 35-75 years of age.

2. T2DM at least for 1 year.

3.Insulin treatment.

4.Attending the endocrinology outpatient clinic.

5. A1c $\geq 7 \%$.

6. Sufficient cognitive maturity to use videophones.

7. No neurological or mental problems.

8. No sight or hearing problems.

9. Oral communication ability.

10. Using videophone technology.

\section{Intervention \\ Study Groups \\ Control Group (CG)}

Routine outpatient clinic monitoring methods were used for the patients in the CG. Patients were consulted at the endocrinology outpatient clinic at which they were being followed up. At face-to-face meetings, the patients' oral and written permission was obtained for participation in the study and use of the questionnaire form. After the third and sixth months, glycaemic control test results and daily blood glucose values were obtained at outpatient clinic consultations. In visits in the 3rd and 6th months, patients were given routine examinations in the diabetes clinic and insulin therapies were reviewed, after which necessary changes were made. Patients in CG were followed up by a hospital team (endocrinologist, dietician, diabetes nurse, etc.) CG support (risk and information management, use of resources etc.) and education on diabetes management were not provided to patients by researchers.

\section{Experimental Group (EG)}

The patients in the EG were also interviewed at the outpatient clinic and their consent for inclusion in the trial was obtained both orally and in writing. The videophone instrument was introduced to patients and they and their companions were shown how to use it; after checks were made at the outpatient clinic, videophone connections at patients' homes were established. Tele-monitoring by the researcher began in the first week after the videophone link had been installed in the patient's home. The information meeting began with the discussion of urgent topics (hyperglycaemia, hypoglycaemia, ketoacidosis, etc.) with the patient and his or her family. The conversations lasted 20 minutes on average.

The conversations were conducted and patients' A1c rates were monitored for medical glycaemic control at the first 
Gungor Tavsanli et al. Journal of Diabetes Research \& Clinical Metabolism 2013,

http://www.hoajonline.com/journals/pdf/2050-0866-2-1.pdf

doi: $10.7243 / 2050-0866-2-1$

Table 1. Distribution of descriptive characteristics of individuals

\begin{tabular}{|c|c|c|c|c|}
\hline Features & $\begin{array}{c}\text { Experiment } \\
\text { Group } \\
\mathbf{N} \\
\end{array}$ & $\begin{array}{c}\text { Experiment } \\
\text { Group } \\
\% \\
\end{array}$ & $\begin{array}{c}\text { Control } \\
\text { Group } \\
\mathrm{N} \\
\end{array}$ & $\begin{array}{c}\text { Control } \\
\text { Group } \\
\% \\
\end{array}$ \\
\hline $\begin{array}{l}\text { Age Group } \\
40-49 \text { years } \\
50-59 \text { years } \\
60-69 \text { years } \\
70-79 \text { years }\end{array}$ & $\begin{array}{c}7 \\
12 \\
3 \\
2\end{array}$ & $\begin{array}{l}29.2 \\
50.0 \\
12.5 \\
8.3\end{array}$ & $\begin{array}{c}7 \\
5 \\
10 \\
2\end{array}$ & $\begin{array}{c}29.2 \\
20.8 \\
41.7 \\
8.3\end{array}$ \\
\hline Average age & $\begin{array}{l}\text { Mean } \pm \text { SD } \\
54.41 \pm 8,54\end{array}$ & $\begin{array}{l}\operatorname{Min}=43 \\
\operatorname{Max}=78\end{array}$ & $\begin{array}{l}\text { Mean } \pm \text { SD } \\
57.25 \pm 9.61\end{array}$ & $\begin{array}{l}\operatorname{Min}=40 \\
\operatorname{Max}=77\end{array}$ \\
\hline $\begin{array}{l}\text { Gender } \\
\text { Female } \\
\text { Male } \\
\end{array}$ & $\begin{array}{l}12 \\
12 \\
\end{array}$ & $\begin{array}{l}50.0 \\
50.0 \\
\end{array}$ & $\begin{array}{l}12 \\
12 \\
\end{array}$ & $\begin{array}{l}50.0 \\
50.0 \\
\end{array}$ \\
\hline $\begin{array}{l}\text { Educational Status } \\
\text { Literate } \\
\text { Primary school } \\
\text { High school or university }\end{array}$ & $\begin{array}{c}3 \\
10 \\
11\end{array}$ & $\begin{array}{l}12.5 \\
41.7 \\
45.8\end{array}$ & $\begin{array}{c}3 \\
16 \\
5\end{array}$ & $\begin{array}{l}12.5 \\
66.7 \\
20.8\end{array}$ \\
\hline $\begin{array}{l}\text { Income Range } \\
\text { Income }<\text { expenditure } \\
\text { Income equal to expenditure } \\
\text { Income }>\text { expenditure }\end{array}$ & $\begin{array}{c}2 \\
17 \\
5\end{array}$ & $\begin{array}{c}8.3 \\
70.8 \\
20.8\end{array}$ & $\begin{array}{c}7 \\
16 \\
1\end{array}$ & $\begin{array}{c}29.2 \\
66.7 \\
4.2\end{array}$ \\
\hline $\begin{array}{l}\text { Insulin treatment } \\
4 \text {-insulin } \\
\text { [Morning + Lunch + Dinner (short-acting) + Night(long-acting) } \\
2 \text {-insulin } \\
\text { [Morning + Dinner (long-acting)] }\end{array}$ & $\begin{array}{l}22 \\
2\end{array}$ & $\begin{array}{l}91.7 \\
8.3\end{array}$ & $\begin{array}{l}22 \\
2\end{array}$ & $\begin{array}{l}91.7 \\
8.3\end{array}$ \\
\hline $\begin{array}{l}\text { Other medications } \\
\text { Antihypertensive and hyperlipidemia medications } \\
\text { Heart medications (coraspirin, Dilatrend, etc.) } \\
\text { Cortisone }\end{array}$ & $\begin{array}{c}17 \\
6 \\
1\end{array}$ & $\begin{array}{c}70.8 \\
25.0 \\
4.2\end{array}$ & $\begin{array}{c}13 \\
11 \\
-\end{array}$ & $\begin{array}{c}54.1 \\
45.9 \\
-\end{array}$ \\
\hline Time from diagnosis of DM (years) & $\begin{array}{l}\text { Mean } \pm \text { SD } \\
11.0 \pm 9.08 \\
\end{array}$ & $\begin{array}{c}\text { Min }=1 \\
\text { Max }=34\end{array}$ & $\begin{array}{l}\text { Mean } \pm \text { SD } \\
7.50 \pm 7.10 \\
\end{array}$ & $\begin{array}{c}\text { Min }=1 \\
M a x=27\end{array}$ \\
\hline Body Mass Index (BMI, $\mathrm{Kg} / \mathrm{m}^{2}$ ) & $\begin{array}{c}\text { Mean } \pm \text { SD } \\
28.82 \pm 5.89\end{array}$ & $\begin{array}{l}\operatorname{Min}=20.96 \\
\operatorname{Max}=44.79\end{array}$ & $\begin{array}{c}\text { Mean } \pm \text { SD } \\
34.82 \pm 1.34\end{array}$ & $\begin{array}{l}\operatorname{Min}=21.94 \\
\operatorname{Max}=45.00\end{array}$ \\
\hline TOTAL & 24 & 100.0 & 24 & 100.0 \\
\hline
\end{tabular}

outpatient clinic visit. After that, videophone monitoring was performed once every week for 6 months. In the third and sixth months, face-to-face information meetings were organized. Patients' medical treatment and examinations were conducted by a hospital team (endocrinologist, dietician, diabetes nurse, etc). The patients were monitored by videophone for a total of 6 months by the researchers (telenursing). The researchers were contacted the patient by videophone every week. Information about the results of blood glucose monitoring and daily living problems (hypoglycemia, insulin administration, weight control, daily stresses, etc.) was given by the diabetes patients. Based on this information, education on diabetes management was provided in 20-minute interviews by videophone. If necessary, an endocrinologist, nutritionist, or other health worker directed, and researchers helped, the management of diabetes.

\section{Hypothesis}

There is a difference between the glycaemic control levels of adults with T2DM who use videophone technology to receive frequent monitoring and those with diabetes mellitus who do not use videophone technology.

\section{Statistical analysis}

The SPSS (Statistical Package for Social Sciences (version 17, Chicago) was used for data analysis. Descriptive statistical methods (frequency, percentage, average, standard deviation) were used for the evaluation of the sociodemographic characteristics and the glycaemic control levels of the diabetes patients. The Repeated Measures Anova was utilised in the comparison of the $\mathrm{HbA1c}$ and blood glucose values recorded over the 6 month monitoring period. The results were bi-directionally evaluated within a $95 \%$ confidence interval and at a significance level of $p<0.05$.

\section{Ethics}

Patients who agreed to participate in the study received the informed consent forms one week before the baseline visit, and signed them before the randomisation. The study was carried out in accordance with the principles of the Helsinki Declaration and was approved by the Ethical Board of the Faculty of Nursing of Ege University (Document number 2009-51).

\section{Results}

The mean age of the individuals in the EG was $54.41 \pm 8.54$ 
Gungar Tavsanli et al. Journal of Diabetes Research \& Clinical Metabolism 2013, http://www.hoajonline.com/journals/pdf/2050-0866-2-1.pdf

doi: $10.7243 / 2050-0866-2-1$

Table 2. Comparison of Blood Glucose Levels in Type 2 Diabetics

\begin{tabular}{|c|c|c|c|c|c|c|}
\hline $\begin{array}{l}\text { Blood glucose } \\
\text { levels }\end{array}$ & $\begin{array}{l}\text { Experiment Group } \\
\text { Mean } \pm \text { Standard Deviation }\end{array}$ & $\begin{array}{l}\text { Control Group } \\
\text { Mean } \pm \text { Standard Deviation }\end{array}$ & $\begin{array}{l}\text { Difference } \\
\text { between the two } \\
\text { groups }\end{array}$ & f & $\mathbf{t}$ & $\mathbf{P}$ \\
\hline Morning FBG & $159.48 \pm 40.71$ & $173.03 \pm 65.07$ & $13.55 \pm 52.89$ & 4.17 & -0.85 & 0.399 \\
\hline Morning PBG & $163.48 \pm 38.64$ & $175.88 \pm 66.69$ & $12.40 \pm 52.66$ & 13.15 & -0.79 & 0.435 \\
\hline Noon PBG & $155.56 \pm 39.86$ & $174.38 \pm 62.55$ & $20.32 \pm 51.20$ & 8.68 & -1.24 & 0.220 \\
\hline Evening PBG & $162.55 \pm 41.29$ & $176.84 \pm 64.70$ & $14.29 \pm 53.49$ & 9.46 & -0.91 & 0.370 \\
\hline
\end{tabular}

- The analysis used independent-sample $t$ tests. • FBG: fasting blood glucose. • PBG: post prandial blood glucose.

Table 3. Comparison of HbA1c Levels in Type 2 Diabetic Individuals

\begin{tabular}{lccccc}
\hline HbA1c & $\begin{array}{l}\text { Experiment Group } \\
\text { Mean } \pm \text { Standard Deviation }\end{array}$ & $\begin{array}{l}\text { Control Group } \\
\text { Mean } \pm \text { Standard Deviation }\end{array}$ & & & f \\
\hline First Observation & $7.79 \pm 0.78$ & $7.92 \pm 2.22$ & 0.95 & -0.26 & 0.796 \\
Second Observation & $7.63 \pm 0.97$ & $8.06 \pm 1.45$ & 1.37 & -1.22 & 0.229 \\
Third Observation & $7.30 \pm 0.79$ & $8.09 \pm 1.28$ & 3.77 & -2.60 & $0.013^{*}$ \\
\hline
\end{tabular}

* The analysis used independent-sample $t$ tests.

years (Min=43 Max=78) and in the CG it was $57.25 \pm 9.61$ (Min=40 Max=77). In both groups, $50 \%$ of the individuals were men and $50 \%$ women. In the EG, $41.7 \%$ had been educated up to primary school level and $45.8 \%$ up to high school or university level. In the CG $66.7 \%$ had been educated up to primary school level and $20.8 \%$ up to high school or university level. In the EG, $70.8 \%$ of patients, and in the CG $66.7 \%$, had an income equal to their expenditure. The mean body mass index of the individuals in the EG was $\left.28.82 \pm 5.89 \mathrm{~kg} / \mathrm{m}^{2} \mathrm{Min}=20.96 \mathrm{Max}=44.79\right)$ and in the CG it was $34.82 \pm 1.34 \mathrm{~kg} / \mathrm{m}^{2}$ (Min=21.94 $\mathrm{Max}=45.00$ ). In both groups, $91.7 \%$ of the individuals used insulin four times daily [Morning + Lunch + Dinner (short-acting) + Night(long-acting)]. In the EG $70.8 \%$ of patients and in the CG $54.1 \%$ used antihypertensive and hyperlipidemia medications (see Table 1).

Videophone monitoring was performed once every week for 6 months. It was shown that postprandial blood glucose levels of the patients in the EG (mean $163.48 \pm 38.64 \mathrm{mg} / \mathrm{dl}$ ) were higher than preprandial blood glucose levels (mean $159.48 \pm 40.71 \mathrm{mg} / \mathrm{dl}$ ) at 6 months. It was determined that preprandial (mean $173.03 \pm 65.07 \mathrm{mg} / \mathrm{dl}$ ) and postprandial (mean $175.88 \pm 66.69 \mathrm{mg} / \mathrm{dl}$ ) blood glucose levels of the patients in the CG were very close to each other at 6 months. When the two groups were compared, it was was found that the morning fast blood glucose levels of patients in the EG (mean $159.48 \pm 40.71 \mathrm{mg} / \mathrm{dl}$ ) were lower by $13.55 \pm 52.89 \mathrm{mg} / \mathrm{dl}$ than the morning fast blood glucose levels of the diabetic patients in the CG (mean 173.03 \pm 65.07 $\mathrm{mg} / \mathrm{dl}$ ) at 6 months. It was determined that the morning post prandial blood glucose levels of patients in the EG $(163.48 \pm 38.64 \mathrm{mg} / \mathrm{dl})$ were lower by $12.40 \pm 52.66 \mathrm{mg} /$ $\mathrm{dl}$ than the morning post prandial blood glucose levels of the diabetic patients in the CG (mean $175.88 \pm 66.69$ $\mathrm{mg} / \mathrm{dl}$ ) at 6 months. Noon post prandial blood glucose levels of patients in the EG $(155.56 \pm 39.86 \mathrm{mg} / \mathrm{dl})$ were lower by $20.32 \pm 51.20 \mathrm{mg} / \mathrm{dl}$ than noon post prandial blood glucose levels of the diabetic patients in the CG (mean $174.38 \pm 62.55 \mathrm{mg} / \mathrm{dl}$ ) at 6 months. Finally, evening post prandial blood glucose levels of patients in the EG $(162.55 \pm 41.29 \mathrm{mg} / \mathrm{dl})$ were lower by $14.29 \pm 53.49 \mathrm{mg} /$ dl than evening post prandial blood glucose levels of the diabetic patients in the CG (mean $176.84 \pm 64.70 \mathrm{mg} / \mathrm{dl}$ ) at 6 months. However, there was no statistically significant difference in blood glucose levels between the groups ( $p>0.05$ ) (Table 2).

Table 3 shows the A1c levels of EG and CG patients in the first, third and the sixth months. It was established that the mean $A 1 c$ value of the individuals in the EG group was $7.79 \pm 0.78 \%$ in the first observation of the monitoring, $7.63 \pm 0.97 \%$ in the second observation in the third month and $7.30 \pm 0.79 \%$ in the third observation in the sixth month.

It was determined that the A1c levels of the individuals in the EG were significantly lower, with a difference of as much as $0.49 \%$ in total at the end of the six-month monitoring.

It was established that the A1c levels of the individuals in the CG were $7.92 \pm 2.22 \%$ in the first observation of the monitoring, $8.06 \pm 1.45 \%$ in the second observation (third month) and $8.09 \pm 1.28 \%$ in the third observation (sixth month) ( $0.03 \%$ higher than the third month value). It was 
determined that the A1c levels of the individuals in the CG were as much as $0.17 \%$ higher than baseline value in total at the end of the six-month monitoring. At six months, it was established that the A1c levels of the individuals in the CG were higher than those of the individuals in the EG by $0.79 \%$ and this difference was found to be statistically significant $(p<0.05)$ (Table 3$)$.

\section{Discussion}

It was found that patients in the EG and CG showed a homogenous distribution in terms of mean age and gender distribution. In developed countries diabetes is an illness seen among people over 64 years old, but it is seen more often in people between the ages of 45 to 64 years in developing countries [21]. In Turkey, at least $10 \%$ of people aged 40 and above are reported to have diabetes [4]. T2DM is most common among those in the over- 60 age group and is more widespread among men than among women $[13,22,23]$. Age, a non-genetic factor, affects the incidence of the illness. The rate of type 2 diabetes in Turkey is $17.2 \%$ among women and $16 \%$ among men [4]. In a study by Buyssea et al., $30.9 \%$ of patients participating in the study were high school and university graduates [24]. In a study by Kartal et al., it was reported that $19.1 \%$ of the patients taking part in the research were high school graduates and $9.1 \%$ were university graduates [21]. In our study, $41.7 \%$ of patients in the EG were educated up to primary school level and $45.8 \%$ up to high school or university level. Also, $66.7 \%$ in the CG were educated up to primary school level and $20.8 \%$ up to high school or university level.

It was was found that at 6 months the morning fast blood glucose levels of the patients in the EG were lower by $13.55 \pm 52.89 \mathrm{mg} / \mathrm{dl}$ than those of the patients in the CG. In a cohort study by Arsand et al., who looked at mobile phone-based self-management tools for type 2 diabetes, it was determined that the blood glucose levels of diabetic patients being tele-monitored by doctors and nurses over six months fell from $160 \mathrm{mg} / \mathrm{dl}$ to $140 \mathrm{mg} / \mathrm{dl}$. This was statistically significant [25] (No p value of in this study).

It was determined that the A1c levels of the individuals in the EG were significinatly lower by $0.49 \%$ in total at the end of the six-month monitoring and that the A1c levels of the individuals in the CG were higher by $0.17 \%$ in total at the end of the six-month monitoring (Table 3). The A1c values of $23.2 \%$ of the individuals participating in the TURDEP study were found to be in the high risk range [4]. The study shows similaries to the prevalence study in Turkey. This conclusion supports the hypothesis: "there is a difference between the glycaemic control levels of diabetic individuals frequently monitored by videophone technology and those who were not monitored by videophone technology or trained face to face.

In a randomized controlled tele-monitoring study by Stone et al. (2010), it was found that the A1c levels of diabetic individuals in a tele-monitoring group were lower by $1.7-0.8 \%$ in the third and sixth months compared with a telephone group $(P<0.001)$ [26]. In a tele medicine cohort study on type 2 diabetics by Kesavadev et al. (2012), it was determined that the mean \pm SD A1c value was $8.5 \pm 1.4 \%$ at the initial visit and was reduced to $6.3 \pm 0.6 \%$ at 6 months $(P<0.0001)$ [27]. In our study similar to these studies, decreased A1c levels were found at sixth months.

In the ELENOR study (2011), tele-care and self blood glucose monitoring groups were compared in type 2 diabetics. The A1c levels of patients who used tele-care fell from $8.8 \%$ to $7 \%$ at the end of the 32 nd week and the A1c levels of patients in the self blood glucose monitoring group fell from $8.9 \%$ to $7.5 \%$ at the end of the 32 nd week. It was shown that the A1c levels of the tele-care group were reduced by $1.8 \%$ and the A1c levels of the other group were reduced by $1.4 \%(P<0.001)[28]$. In a tele-medicine study on type 2 diabetics by Narayanan et al. (2012), the A1c levels of diabetic patients were $9 \%$ higher than at first. It was found that the A1c levels of diabetic patients were $0.03 \%$ lower at the end of the third year, $0.28 \%$ lower at the end of the second year and $0.56 \%$ lower at the end of the first year [29]. The authors failed to find a significant difference in HbA1c between the two groups. Similarly, these studies showed an improvement in glycaemic control using tele-medicine.

In a meta-analysis examining the effect on diabetes management by mobile phones by Liang et al. (2010), data from twenty-two studies performed between 2004 and 2010 were investigated. Ten studies were performed to monitor the six month average of A1c levels with type 2 diabetics [30]. In subgroup analysis, 11 studies of Type 2 diabetes patients reported significantly greater reduction in $\mathrm{HbA1c}$ than studies of Type 1 diabetes patients (0.8 $0.3 \% ; \mathrm{P}=0.02$ ). In a meta-analysis, randomized controlled studies found that the A1c levels of patients were $0.2-0.8 \%$ lower than other studies with non-randomized designs. In initiatives (most trials used a mobile phone short message service (SMS) to deliver blood glucose test results and selfmanagement information) it wass established that the daily, weekly and monthly A1c levels of patients were reduced by $0.6 \%$ by mobile phone intervention. The meta-analysis study showed that tele-medicine intervention methods for diabetes care led to statistically significant improvements in glycaemic control and self management [30].

Tele-monitoring is an increasingly used treatment approach to chronic diseases. The approach reinforces the collection and interpretation of disease symptoms and findings, and attempts at disease prevention. In recent times the application of modern technologies such as e-health, tele-care and tele-medicine has been targeted at the treatment of diabetes patients. The increase in the use of technology in diabetes treatment allows improved communication between nurses and patients, the collection of reliable information, and the provision 
of a comfortable life to patients. Yes, my comments. So, I took out resource numbers.

The needs of patients with different metabolic control needs are met through the use of technical instruments such as videophones.

\section{Limitations}

In this study, Turk Telekom sponsored videophone equipment and installations, and internet connections. The study was not continued for a longer period than six months due to financial limitations, and large groups and multi-center studies were not performed.

\section{Conclusions}

When the two groups in the study were compared, it was was found that the A1c and blood glucose levels of the diabetic patients in the EG were lower of than those of the individuals in the CG. This showed that videophone technology can be useful in the glycaemic control of diabetic patients in Turkey.

\section{Competing interests}

The authors declare that they have no competing interests.

\section{Authors' contributions}

NGT, AK, FS made substantial contributions to the conception and design, NGT was involved in the acquisition of data, and NGT, AK and FS were involved in the analysis and interpretation of data. All authors were fully responsible for all content and editorial decisions, were involved at all stages of manuscript development, and approved the final version.

\section{Acknowledgement}

We are grateful for the support of the Turkish Telecom Management for the allocation, installation and service of videophone devices.

\section{Further Research}

Decreases in $\mathrm{HbA1c}$ and blood glucose levels within a period of six months were determined with the help of videophone techniques. Accordingly, it can be stated that videophone techniques are efficient in glycaemic monitoring of diabetes patients. Further research in well-designed trials with large sample size is needed to further demonstrate how videophone intervention can enhance diabetes care and management support.

\section{Publication history}

Received: 27-Nov-2012 Revised: 24-Dec-2012

Re-Revised: 31-Dec-2012 Accepted: 09-Jan-2013

Published: 18-Jan-2013

\section{References}

1. Bird D, Oldenburg B, Cassimatis M, Russell A, Ash S, Courtney MD, Scuffham PA, Stewart I, Wootton R, Friedman RH: Randomised controlled trial of an automated, interactive telephone intervention to improve type 2 diabetes self-management (Telephone-Linked Care Diabetes Project): study protocol. BMC Public Health 2010, 10:599. | Article | PubMed Abstract | PubMed Full Text

2. The Turkish health goverment Website. The epidemiology of diabetes mellitus. [25 April 2008]. | Website

3. Logtenberg SJ, van Ballegooie E, Israel-Bultman H, van Linde A, Bilo $\mathrm{HJ}$ : Glycaemic control, health status and treatment satisfaction with continuous intraperitoneal insulin infusion. Neth J Med 2007, 65:65-70. | Pdf | PubMed

4. Satman I., Yılmaz T., Şengül A. and et.al. c: National Diabet Congress Books. Rixos Sungate Hotel, Antalya, Turkey, May 2011, 22:11-15.

5. Montori VM, Helgemoe PK, Guyatt GH, Dean DS, Leung TW, Smith SA, Kudva YC: Telecare for patients with type 1 diabetes and inadequate glycemic control: a randomized controlled trial and meta-analysis. Diabetes Care 2004, 27:1088-1094. | Article | PubMed

6. Chang K, Davis R, Birt J, Castelluccio P, Woodbridge P, Marrero D: Nurse Practitioner - Based Diabetes Care Management Impact of Telehealth or Telephone Intervention on Glycemic Control. Dis Manage Health Outcomes 2007, 15:377-385. | Article

7. Jaana M, Pare G: Home telemonitoring of patients with diabetes: a systematic assessment of observed effects. J Eval Clin Pract 2007, 13:242-253. | Article | PubMed

8. Schope A.C., Balakas K., Rice R: Telemedicine, Telecare and Telenursing. Application and Concept of Home Care Nursing, Mosby Copration, London, 2006, 420-456.

9. Craig J., Patterson V. Introduction to the practice of telemedicine (section 1)- Introduction to Telemedicine. Second Edition, In: Wootton R., Craig J., Patterson V, eds. Royal Society of Medicine Press Ltd., London UK, ISBN: 1- 85315-677-9, 2006, 1-14. | Pdf

10. Darkins A.W., Cary M.A. Telemedicine and Telehealth Principles, Policies, Performance and Pitfalls, Springer Publishing Company Inc, New York, ISBN: 0-8261-1302-8, 2000,1-25. | Book

11. Horton K: The use of telecare for people with chronic obstructive pulmonary disease: implications for management. J Nurs Manag 2008, 16:173-180. | Article | PubMed

12. Wojcicks JM., Ladyzynski P. Telematic support in intensive insulin treatment. Frequency of the data transfer. Diabetes Research and Clinical Practice 2006, 74: 225-228. | Article

13. Kim. G., Shin D. H., Jeong M.H., Park J.R., Lee Y.J., Yoo H.J., Park S.Y., Ryu O.H., Kim H.Y., Choi D.S., Baik S.H., Choi D.S., Yang S.J. The Effect of Diabetes Mobile Phone Based Telecare on Glycemic Control in Subjects with Type 2 Diabetes, Diabetes 2007, 1:116-117. I Article

14. Moehr JR, Schaafsma J, Anglin C, Pantazi SV, Grimm NA, Anglin S: Success factors for telehealth--a case study. Int J Med Inform 2006, 75:755-763. | Article | PubMed

15. Franc S, Daoudi A, Mounier S, Boucherie B, Dardari D, Laroye H, Neraud B, Requeda E, Canipel L, Charpentier G: Telemedicine and diabetes: achievements and prospects. Diabetes Metab 2011, 37:463-476. | Article | PubMed

16. Rothman R, Malone R, Bryant B, Horlen C, DeWalt D, Pignone M: The relationship between literacy and glycemic control in a diabetes disease-management program. Diabetes Educ 2004, 30:263-273. | Article | PubMed

17. Kollmann A, Riedl M, Kastner P, Schreier G, Ludvik B: Feasibility of a mobile phone-based data service for functional insulin treatment of type 1 diabetes mellitus patients. J Med Internet Res 2007, 9:e36. | Article | PubMed Abstract | PubMed Full Text

18. Jaana M, Pare G: Home telemonitoring of patients with diabetes: a systematic assessment of observed effects. J Eval Clin Pract 2007, 13:242-253. | Article | PubMed

19. Farmer A, Gibson OJ, Tarassenko L, Neil A: A systematic review of telemedicine interventions to support blood glucose self-monitoring in diabetes. Diabet Med 2005, 22:1372-1378. I Article | PubMed

20. From Wikipedia, the free encyclopedia, "Systematic sampling", [25 December 2012]. Website

21. Kartal A., Çağırgan G., Tığı H., Güngör Y., Karakuş N., Gelen M: Factors Iwnfluencing Attitudes and Attitude Intanded for Care and Treatment of Type 2 Diabetic Patients. TAF Prev Med Bull 2008, 3:223-230.

22. ADA - American Diabetes Assocation Website. [14 October 2012]. Website 
23. Biçer K. E., Özyazar M., Çevik B. A: Fiscal Costs And Complications in Endocrinology, Diabetes and Metabolism Clinic Hospitalized Diabetic Patients. Nursing Forum in Hypertension and Obesity, Diabetes 2009, 2:6-13.

24. Buysse HE, Coorevits P, Van Maele G, Hutse A, Kaufman J, Ruige J, De Moor GJ: Introducing telemonitoring for diabetic patients: development of a telemonitoring 'Health Effect and Readiness' Questionnaire. Int J Med Inform 2010, 79:576-584. | Article | PubMed

25. Arsand E, Tatara N, Ostengen G, Hartvigsen G: Mobile phonebased self-management tools for type 2 diabetes: the few touch application. J Diabetes Sci Technol 2010, 4:328-336. | Article | PubMed Abstract | PubMed Full Text

26. Stone RA, Rao RH, Sevick MA, Cheng C, Hough LJ, Macpherson DS, Franko CM, Anglin RA, Obrosky DS, Derubertis FR: Active care management supported by home telemonitoring in veterans with type 2 diabetes: the DiaTel randomized controlled trial. Diabetes Care 2010, 33:478-484. | Article | PubMed Abstract | PubMed Full $\underline{\text { Text }}$

27. Kesavadev J, Shankar A, Pillai PB, Krishnan G, Jothydev S: Costeffective use of telemedicine and self-monitoring of blood glucose via Diabetes Tele Management System (DTMS) to achieve target glycosylated hemoglobin values without serious symptomatic hypoglycemia in 1,000 subjects with type 2 diabetes mellitus--a retrospective study. Diabetes Technol Ther 2012, 14:772-776. | Article | PubMed

28. Del Prato S, Nicolucci A, Lovagnini-Scher AC, Turco S, Leotta S, Vespasiani G: Telecare Provides comparable efficacy to conventional self-monitored blood glucose in patients with type 2 diabetes titrating one injection of insulin glulisine-the ELEONOR study. Diabetes Technol Ther 2012, 14:175-182. | Article | PubMed

29. Narayanan RP, Mason JM, Taylor J, Long AF, Gambling T, New JP, Gibson JM, Young RJ: Telemedicine to improve glycaemic control: 3-year results from the Pro-Active Call Centre Treatment Support (PACCTS) trial. Diabet Med 2012, 29:284-285. | Article | PubMed

30. Liang X, Wang Q, Yang X, Cao J, Chen J, Mo X, Huang J, Wang L, Gu D: Effect of mobile phone intervention for diabetes on glycaemic control: a meta-analysis. Diabet Med 2011, 28:455-463. | Article | PubMed

\section{Citation:}

TavşAnli N G, Karadakovan A and Saygili F: The use of videophone technology (telenursing) in the glycaemic control of diabetic patients: a randomized controlled trial. Journal of Diabetes Research and Clinical Metabolism 2013, 2:1. http://dx.doi.org/10.7243/2050-0866-2-1 